\title{
The ecology of Dunaliella in high-salt environments
}

\author{
Aharon Oren
}

\begin{abstract}
Halophilic representatives of the genus Dunaliella, notably D. salina and D. viridis, are found worldwide in salt lakes and saltern evaporation and crystallizer ponds at salt concentrations up to $\mathrm{NaCl}$ saturation. Thanks to the biotechnological exploitation of $D$. salina for $\beta$-carotene production we have a profound knowledge of the physiology and biochemistry of the alga. However, relatively little is known about the ecology of the members of the genus Dunaliella in hypersaline environments, in spite of the fact that Dunaliella is often the main or even the sole primary producer present, so that the entire ecosystem depends on carbon fixed by this alga. This review paper summarizes our knowledge about the occurrence and the activities of different Dunaliella species in natural salt lakes (Great Salt Lake, the Dead Sea and others), in saltern ponds and in other salty habitats where members of the genus have been found.
\end{abstract}

Keywords: Dunaliella, Hypersaline, Halophilic, Great Salt Lake, Dead Sea, Salterns

\section{Introduction}

When the Romanian botanist Emanoil C. Teodoresco (Teodorescu) (1866-1949) described the habitat of the new genus of halophilic unicellular algae Dunaliella, it was known from salterns and salt lakes around the Mediterranean and the Black Sea [1-3]. He named the alga in honor of Felix Dunal who in 1838 had described such red-colored unicellular algae growing in the brines of solar salterns [1,3]. Today we known halophilic members of the genus Dunaliella to occur in hypersaline environments worldwide as the main and often as the sole primary producer, especially at the highest salt concentrations where other oxygenic phototrophs cannot grow $[2,4]$.

In more than a century since the first description of Dunaliella, some representatives of the genus became popular research objects. A search in ISI Web of Science (accessed on 21.9.2014) yielded 1762 papers in which the name features in the title, with $\sim 60$ such papers per year in the past decade. This interest is to a large extent due to the exploitation of some halophilic isolates for the commercial production of $\beta$-carotene and other valuable products. Some strains are used as model organisms for basic studies in photosynthesis research and

Correspondence: aharon.oren@mail.huji.ac.il

Department of Plant and Environmental Sciences, The Alexander Silberman Institute of Life Sciences, The Hebrew University of Jerusalem, Edmond J. Safra Campus, Jerusalem 91904, Israel salt adaptation. A number of books and review papers have therefore been devoted to the genus [5-7]. However, the ecological aspects of the biology of Dunaliella are generally neglected. A recent monograph did not devote a single chapter to ecological aspects, and contained hardly any information about the dynamics and in situ activities of natural populations in those ecosystems in which the alga grows $[7,8]$.

I here review the current information about the abundance and the activities of the halophilic members of the genus Dunaliella and their interactions with the other components of their hypersaline habitats. Although freshwater and marine species of the genus (which seldom, if ever) are quantitatively important in their ecosystem, they are not discussed here.

\section{Review}

\section{Taxonomy of the genus Dunaliella}

In spite of many efforts to establish order, the taxonomy of the genus Dunaliella is very confusing [9]. Many of the described and named species were observed only rarely, and the introduction of molecular DNA sequence-based approaches has done little to solve the problems of the classical morphology-based taxonomy.

Older morphology-based studies [10-12] led to the recognition of 28 species, 14 of which can be classified as halophilic with salt optima between 6 and 12\%: in the 
"Section Dunaliella": D. parva, D. salina and D. pseudosalina, and in the "Section Viridis": D. ruineniana, D. gracilis, $D$. bioculata, $D$. carpatica, $D$. granulata, $D$. baasbeckingii, $D$. minuta, D. media, D. minutissima, $D$. terricola, and $D$. viridis [12]. This list does not include $D$. bardawil, often considered a form of $D$. salina. This classification was also adopted in the recent monograph on the genus [13]. A reevaluation of the genus published in 2007 listed 22 species, including 17 halophiles (D. asymmetrica, D. peircei, and D. turcomanica, in addition to the above-listed species). The non-carotenogenic D. media, D. ruineniana, D. gracilis, and $D$. baasbeckingii are known from one field collection only [14].

The species most often reported from natural salt lakes and saltern ponds are $D$. salina and $D$. viridis. Both have a wide salt range, from 9-200 $\mathrm{g} \mathrm{l}^{-1} \mathrm{NaCl}$ to saturation. Dunaliella viridis grows optimally at $60-90 \mathrm{~g} \mathrm{l}^{-1}$ $\mathrm{NaCl}$, D. salina at $\sim 100-150 \mathrm{~g} \mathrm{l}^{-1}$, i.e., concentrations much below the salt concentrations of the environments where halophilic Dunaliella species generally thrive [15]. This aspect is further discussed below.

Molecular techniques were introduced in the taxonomy of Dunaliella about 15 years ago [13,16,17]. These studies are mostly based on (1) $18 \mathrm{~S}$ rRNA gene sequences, (2) the number and positions of introns in that gene [17-20], and (3) the sequence of the internal transcribed spacer regions ITS1 and ITS2 in the rRNA gene cluster and the $5.8 \mathrm{~S}$ rRNA gene in-between. In addition to sequencing of the genes and gene fragments, fingerprinting techniques such as Restriction Fragment Length Polymorphism were employed [17]. In some studies the gene encoding the large RuBisCo subunit $(r b c L)$ was also included [21].

Sequence comparisons confirmed the monophyly of the subgenus Dunaliella [22], but within this subgenus $D$. viridis was found to consist of at least four clades and D. salina of three [23]. It became clear that many culture collection strains had been mislabeled [17]. DNA fingerprinting and intron-sizing methods may be suitable for specific, rapid, and sensitive identification of Dunaliella species $[19,24]$, but no correlation was shown between the genetic relationship inferred from ITS-RFLP data and the morphological and physiological attributes [16].

In ecological studies, such molecular methods were seldom exploited to obtain information about the population structure of Dunaliella. The technique was used in a biogeographic study of $D$. salina: sequence comparison of the primary and secondary structure of the ITS2 sequences and Compensatory Base Changes analyses (where both nucleotides of a paired site mutate while pairing is maintained) did not yield clear geographyrelated signals [25].

Culture-independent small-subunit rRNA-based and metagenomic studies were performed in many hypersaline environments, including Great Salt Lake, the Dead
Sea, and solar salterns. However, such studies did not contribute to our understanding of the structure of Dunaliella communities in such ecosystems. Most environmental genomic studies targeted "prokaryotic" $16 \mathrm{~S}$ rRNA genes, neglecting eukaryotic 18S rRNA genes. The study of $18 \mathrm{~S}$ rRNA sequences along two depth profiles in Great Salt Lake in 2007 [26] is a rare exception. As numbers of Dunaliella and other eukaryotes are typically four or more orders of magnitude lower than those of the prokaryotes in the community, Dunaliella-derived genes are never conspicuously present in metagenomic libraries. For example, no Dunaliella-related sequences were found in fosmid clones prepared from DNA extracted from the 1992 microbial bloom in the Dead Sea [27]. A notable exception is the characterization of eukaryotic microbial diversity in hypersaline Lake Tyrrell, Victoria, Australia, based on 18S rRNA gene inventories [28], further discussed below.

The earliest descriptions of Dunaliella mentioned the possibility of formation of palmelloid cells and resting cysts (aplanospores). Encysted zygotes resulting from gamete union in sexual reproduction were also described $[10,29]$. Under non-optimal salt concentrations caused by drastic dilution of the medium or drying-up of the environment, cells may form asexual thick-walled nonmotile cysts with bumpy surfaces, often referred to as aplanospores $[9,12,14,30]$. In $D$. salina, such aplanospores contain canthaxanthin as the main carotenoid rather than $\beta$-carotene found in the vegetative cells [15]. In a study of $D$. salina from saline environments of the central coast of Peru, formation of spherical, reddish aplanospores were observed when collected plankton samples were kept in the laboratory for a few days [31]. In Great Salt Lake, round cyst-like cells of $D$. salina increased in numbers, especially on the bottom, when the temperature decreased below $0^{\circ} \mathrm{C}$ [32]. In the Dead Sea such cysts may play a key function in long-term survival of Dunaliella in a lake that is now generally too extreme to support algal growth (see below). Remote sensing showed that the bloom that started in April 1992 following dilution of the upper water layers originated in the shallow near-shore areas. It was probably derived from resting cells that survived in the shallow sediments [33]. Formation of thick-walled cysts was observed during the decline of this bloom [34].

Palmelloid stages, in which non-motile cells are encased in a gelatinous mass of mucus, may also form under certain conditions $[10,12]$. In hypersaline pools of $16.5-35 \%$ salt on the central coast of Peru, benthic palmelloid stages of $D$. salina were found at the higher salinities. Palmelloid benthic forms were seen mainly in winter at depths up to $1 \mathrm{~m}$ as irregular and lobulated clusters up to $3 \mathrm{~mm}$ in diameter. Nutrient deficiency, low temperature and low salinity may trigger the production of these palmelloid forms [31]. 


\section{Dunaliella in hypersaline environments - Case studies Great Salt Lake}

Surprisingly, little recent information is available about Dunaliella in Great Salt Lake, where it is the main (or the only) primary producer in the north arm and an important component of the phototrophic community in the south arm. Both green $D$. viridis and $\beta$-carotene-rich $D$. salina play a role in the ecosystem. Most studies date from the 1970s and 1980s, and these were reviewed earlier [32,35]. Two papers published in 2013 [26,36] do little to complete the picture. This is to be regretted as Great Salt Lake is a dynamic ecosystem that has undergone dramatic changes in water level and accordingly in salinity in the past decades. The lake is divided by a railway causeway into a less saline southern part and a hypersaline north arm that now approaches $\mathrm{NaCl}$ saturation.

In the 1970 s, D. salina was the dominant planktonic alga in the north arm $\left(\sim 332 \mathrm{~g} \mathrm{l}^{-1}\right.$ salt $)$, with typical population densities of 200-1000 cells $\mathrm{ml}^{-1}$ and peak densities of 3000 to 10000 cells $\mathrm{ml}^{-1}$. Its horizontal distribution was highly patchy. Dunaliella viridis was found in the north arm mostly on the underside of rocks and wood along the shallow margin, out of direct sunlight $[32,37]$. In the water column, D. viridis densities were sometimes higher in the deeper layers than at the surface. Thus, a density of 4000 cells $\mathrm{ml}^{-1}$ was recorded at $4.5 \mathrm{~m}$ depth in the north arm in August 1975, an order of magnitude higher than the numbers in the upper $1.5 \mathrm{~m}$. Whether this vertical distribution was caused by supraoptimal light intensities at the surface or by nutrient availability is unknown. Ammonium is the key nutrient controlling biological processes in the lake [32,38]. When (in the summer of 1977) a severe drought caused the north arm to shrink and a crust of $\mathrm{NaCl}$ formed on the shore, massive development of Dunaliella below the 3-4 cm thick salt crust was observed with up to 35000 D. salina and 2000 D. viridis cells $\mathrm{g}^{-1}$ salt. Oxygen production by the algae led to the elevation of parts of this crust as 7-15 cm-large 'salt domes' [39].

In the less saline $\left(\sim 117 \mathrm{~g} \mathrm{l}^{-1}\right)$ south arm, D. viridis dominated the phytoplankton in the 1970s, with densities exceeding 1000 cells $\mathrm{ml}^{-1}$. Short-lived blooms with up to 25000 cells $\mathrm{ml}^{-1}$ were recorded in the spring of 1971 and 1973 [32,40].

Primary production measurements based on ${ }^{14} \mathrm{CO}_{2}$ incorporation in the water column at two stations in the south arm in 1973 yielded an estimate of $\sim 145 \mathrm{~g} \mathrm{C}$ $\mathrm{m}^{-2}$ year $^{-1}$. The highest activity was recorded during the Dunaliella bloom in March-April (2.13 $\mathrm{g} \mathrm{C} \mathrm{m}^{-2}$ day $\left.^{-1}\right)$. In winter, temperatures were too low; in summer, production was limited by nitrogen availability and by grazing by the brine shrimp Artemia [40].

The 1970s and 1980s were a period of increased precipitation in the area. As a result the salinity of Great
Salt Lake decreased greatly. By 1986, the salt concentration in the south arm had dropped to $\sim 60 \mathrm{~g} \mathrm{l}^{-1}$. Halophilic Dunaliella species were outcompeted by other phototrophs, especially the cyanobacterium Nodularia [41]. Then the lake level dropped again, and in the last decade the salt concentrations in the south and the north arm were around 140-150 $\mathrm{g} \mathrm{l}^{-1}$ and 270-300 $\mathrm{g} \mathrm{l}^{-1}$, respectively.

In recent years, in-depth molecular studies of the biota of Great Salt Lake were initiated, aimed at an understanding of the prokaryote diversity. Eukaryotic diversity, as monitored by $18 \mathrm{~S}$ rRNA gene sequences recovered from environmental DNA, was included in an analysis of a depth profile at one station in the south arm and one station in the northern part in June 2007. Dunaliella-related sequences formed $71-96 \%$ of the eukaryote sequences in the south arm profile $(0,4,6,6.5$ and $8 \mathrm{~m}$ depth) [26]. Microcosms (400 ml) were set up with water from the south arm to study the effect of salinity and nutrient levels on the biota. The relative abundance of $D$. viridis increased with increasing salinity (up to $150 \mathrm{~g} \mathrm{l}^{-1}$ ), especially at the lower temperatures tested $\left(10-20^{\circ} \mathrm{C}\right)[36]$.

\section{The Dead Sea}

Currently, no Dunaliella cells can be found in the waters of the Dead Sea. The negative water balance and the increase in divalent cation concentrations (>2 $\mathrm{M} \mathrm{Mg}^{2+}$, $\sim 0.5 \mathrm{M} \mathrm{Ca}^{2+}$ ) has made the lake an environment too hostile even for the most salt-tolerant algal genus. But in the past, Dunaliella has been present in large numbers during periods when the salinity of the upper water layers was lower than today. Its development has at least twice triggered the development of dense blooms of red halophilic Archaea: in 1980 and in 1992, after dilution of the upper meters of the water column following unusually rainy winters $[42,43]$. Dunaliella cells, identified as $D$. viridis, were first cultured from Dead Sea water in enrichment cultures with 75\% Dead Sea water and 25\% fresh water in the late 1930s [44,45]. Later isolates were identified as D. parva [46,47]; see [42] for further comments about the identification at the species level. Red, $\beta$-carotene-rich types were never encountered. Development of Dunaliella in the Dead Sea is restricted not only by the generally too high salinities and the unfavorable ionic composition of the brine, but also by lack of phosphate, the limiting nutrient [48].

Quantitative information about the population dynamics of Dunaliella in the Dead Sea prior to 1980 is scarce. Up to 40000 cells $\mathrm{ml}^{-1}$ were reported in surface water in 1964 (sampling date not specified), when the lake was still meromictic (a period that ended with the overturn of the water column in February 1979). At $50 \mathrm{~m}$ depth numbers were two orders of magnitude lower, and no 
algal cells were encountered at $100 \mathrm{~m}$ depth [49]. A bloom of up to 8800 cells ml $^{-1}$ developed in the upper $5-10 \mathrm{~m}$ of the water column in the summer of 1980 after massive amounts of rain water had entered the lake during the preceding winter, starting a new meromictic episode that lasted until the end of 1982. The algal population was distributed evenly over the mixed layer above the pycnocline [47]. Then, a period of ten years followed, in which no Dunaliella cells were observed in the many water samples examined. The upper meters of the lake's water column once more became greatly diluted, this time down to $\sim 70 \%$ of the original salinity, during the rainy winter of 1991-1992. A new Dunaliella bloom rapidly developed in April-May 1992 with densities up to 15000 cells $\mathrm{ml}^{-1}$, evenly distributed down to the pycnocline located at $5 \mathrm{~m}$ depth [34]. As explained above, thick-walled cysts found within the shallow sediments may have formed the inoculum that enabled the development of the new bloom; the lowered salinity probably triggered their germination [33]. From August 1992 onwards, Dunaliella cells started to appear near the pycnocline in numbers up to 1850 cells $\mathrm{ml}^{-1}$; a year later this 'deep chlorophyll maximum' was found at $14 \mathrm{~m}$ depth $\left(\sim 3000\right.$ cells $\left.\mathrm{ml}^{-1}\right)$. Occurrence of healthy, motile Dunaliella cells at these depths, at low light intensities and at salinities generally considered too high for growth, may be related to the availability of nutrients, especially phosphate that may have been depleted in the surface waters [34]. During the 1992 bloom, attempts were made to estimate primary production using ${ }^{14} \mathrm{C}$-bicarbonate as a tracer. Maximum estimated values recorded in May, at the peak of the bloom, were $\sim 142 \mathrm{mg}$ $\mathrm{Cl}^{-1} \mathrm{day}^{-1}$ and an integrated value of $\sim 0.66 \mathrm{~g} \mathrm{C} \mathrm{m}^{-2} \mathrm{day}^{-1}$. These measurements were supplemented with stable isotope studies in which changes in the ${ }^{13} \mathrm{C}$ content of the dissolved inorganic carbon were related to biological phenomena [34].

After a new overturn of the water column in the end of 1995, ending a four-year meromictic episode, conditions in the Dead Sea never became suitable again for development of Dunaliella.

\section{Other natural lakes}

The community of Dunaliella and other eukaryotes in Lake Tyrrell, an ephemeral thalassohaline lake near Melbourne, Australia, was characterized using molecular techniques. In the water column Dunaliella represented $3.4 \%$ of the sequences in summer (250-300 $\mathrm{g} \mathrm{l}^{-1}$ salt) and $2.4 \%$ in winter $\left(>330 \mathrm{~g} \mathrm{l}^{-1}\right.$ salt). The dominant planktonic eukaryote was a novel type of the Alveolate Colpodella. But within the up to $7-\mathrm{cm}$ thick halite crust that formed in winter, $91.1 \%$ of the $18 \mathrm{~S}$ genes detected in clone libraries were related to $D$. salina, $D$. parva, and $D$. viridis. The halite crust may provide a refuge from predation, leading to dominance of Dunaliella [28].

A survey of 53 saline lakes in Antarctica showed Dunaliella to be present in three lakes only: Deep Lake and Lake Stinear (Vestfold Hills) and Lake Hunazoko in Skarvs Nes [50].

\section{Solar salterns}

Dunaliella was first spotted in saltern evaporation and crystallizer brines [1-3,29] and relatively much information is available about the occurrence of the genus in salterns worldwide [51-55]. In crystallizer ponds, D. salina is found in numbers that vary from $\sim 150$ to $\sim 3000$ cells $\mathrm{ml}^{-1}$ in the oligotrophic salterns of Eilat, Israel up to a maximum of 100000 cells $\mathrm{ml}^{-1}$ recorded in a Spanish saltern pond [55]. In extremely oligotrophic salterns, D. salina may be altogether absent $[56,57]$. Growth can be highly patchy: in a single pond of the Santa Pola salterns (Alicante, Spain) with $370 \mathrm{~g} \mathrm{l}^{-1}$ salt, cell numbers varied between 5090 and 10500 per $\mathrm{ml}$, with chlorophyll $a$ concentrations between 23.6 and $45.7 \mu \mathrm{g} \mathrm{l}^{-1}$ [54]. A study in evaporation ponds of relatively low salinity (up to $144 \mathrm{ppt}$ ) at the Megalon Embolon saltworks in northern Greece showed D. salina to represent $5-22 \%$ of the total microalgal assemblage in spring; values decreased to $0.3-1 \%$ during summer as a result of grazing by the brine shrimp and ciliate protozoa. Salinity and phosphate availability were further identified as the main factors affecting Dunaliella growth [58].

Dunaliella salina with its high $\beta$-carotene content is not the only red-pigmented microorganism in saltern crystallizer brines: it is accompanied by a community of halophilic Archaea (family Halobacteriaceae), colored pink-red by the carotenoid $\alpha$-bacterioruberin and derivatives and possibly also by bacteriorhodopsin and other retinal-containing membrane proteins. An additional pigment that may be present is salinixanthin of Salinibacter (Bacteroidetes) [59]. In all systems investigated the pigment present in the largest amounts in such brines is $\beta$-carotene. It is densely packaged as globules within the interthylakoid space of the cell's single chloroplast. As a result it contributes relatively little to the overall color of the brine, which is dominated by bacterioruberin of the Archaea. For quantitative recovery of the pigments, filtration is the appropriate method; during centrifugation of the brine, D. salina cells often tend to float, so that very little $\beta$-carotene is recovered in the pellet [60-62].

Polysaccharides excreted by the biota of saltern ponds can negatively affect the quality and the quantity of the salt produced. Most problems caused by accumulation of polysaccharides in crystallizer brines are due to massive development of unicellular cyanobacteria (Aphanothece) at lower salinities. However, D. salina may also produce 
extracellular polymeric substances, especially at elevated salt concentrations [63]. There are reports showing that release of organic substances by Dunaliella may negatively affect size and quality of the $\mathrm{NaCl}$ crystals formed [64-66]. However, to what extent accumulations of Dunaliella rather than of cyanobacteria are the true cause of the production of poor quality salt remains unclear.

\section{Hypersaline soils and spider webs in desert caves}

Dunaliella is a typically aquatic genus. However, a community of Dunaliella was found in hypersaline soils of the Great Salt Plains, Oklahoma. It included motile single cells, a palmelloid phase with non-motile cells and mucilage, and palmelloid forms with weak motility. Based on 18S rRNA sequence data the diverse lineages found were affiliated with $D$. viridis [67].

Even more unexpected is the finding of a novel subaerial Dunaliella species growing on spiderwebs on the wall of a cave in the Atacama Desert, Chile. The entrance to the cave confronts the Pacific Ocean, receiving more humid air coming from the ocean. The algae exploit the air moisture condensing on the spiderweb silk threads. Based on gene sequence information (18S rRNA, chloroplast $16 \mathrm{~S}$ rRNA, the photosystem I reaction center gene $p s a B$ and the large RuBisCo subunit $r b c L$ ), the organism is a member of the Dunaliella genus, and it was named $D$. atacamensis. Thus far it has not been brought into culture, and its salt requirement and tolerance are yet unknown [68].

\section{Brine inclusions in crystals of halite or gypsum}

When salt crystallizes from $\mathrm{NaCl}$-saturated solutions, the halite crystals often contain brine inclusions. Microorganisms living in the brine can become trapped in these inclusions. Different types of halophilic prokaryotes, Archaea as well as Bacteria, could be revived from brine inclusions within salt deposited tens to hundreds of thousands of years ago. Dunaliella-like cells are may also be found within such brine inclusions. Thus, remains of large carotenoid-rich cells resembling $D$. salina were observed within 10-34 k.y. and 100 k.y. old halite crystals in a core from Death Valley, CA. Presence of algal cells within brine inclusions explains in part the longevity of the prokaryotes present: the dying algae may have supplied an abundant source of carbon and energy, including a large amount of glycerol accumulated for osmotic stabilization [69-73].

Pale-yellow pigmented algal cells were observed within fluid inclusions entrapped in halite deposited from Lake Magic, an ephemeral acidic (pH 1.7) and hypersaline ( $325 \mathrm{~g} \mathrm{l}^{-1}$ salt) lake in Western Australia [74]. These cells were interpreted as Dunaliella algae. Such algae were also found, together with pennate diatoms and different types of prokaryotes, within gypsum crystals precipitated from acid ( $\mathrm{pH}$ 1.8-4.6) saline (5-28\%) water at Salars Gorbea and Ignorado in the high Andes of northern Chile [75]. Also here, further study of the taxonomic affiliation of these algae is necessary.

\section{In situ activities of Dunaliella in hypersaline environments} The above survey of hypersaline habitats where Dunaliella spp. are found demonstrates that the alga is generally found at salinities much higher than the optimum values for growth. In culture, $D$. salina grows optimally at $\sim 100-150 \mathrm{~g} \mathrm{l}^{-1}$ salt, and D. viridis at $\sim 60-90 \mathrm{~g} \mathrm{l}^{-1}$. In nature they are seldom found at these salinities as they are outcompeted by other, faster-growing phototrophs, eukaryotic as well as prokaryotic. Thanks to their ability to grow at salt concentrations up to saturation, Dunaliella species dominate the ecosystem at the highest salinities where they lack competitors $[15,66,76]$.

While in the athalassohaline salt-saturated environment of the Dead Sea only smaller green types were found, the large-celled $D$. salina generally outcompetes $D$. viridis and $D$. parva in $\mathrm{NaCl}$-dominated brines approaching saturation. This is illustrated in a study in Hutt Lagoon, a hypersaline lagoon in Western Australia where $D$. salina is grown for $\beta$-carotene production. In summer, both species survive below the halite layer of the dry lake bed. Upon winter flooding the cells are released into the water column. When the salt concentration increases above $250 \mathrm{~g} \mathrm{l}^{-1}, D$. viridis migrates to the bottom, but $D$. salina remains active in the water column up to a salt concentration of $310 \mathrm{~g} \mathrm{l}^{-1}$. Thanks to its high carotenoid content, $D$. salina is better adapted to high light intensities than $D$. viridis [77].

It is surprising how little we know about the activity of Dunaliella populations in their natural habitats. There are only few estimates of primary production and in situ growth rates. This is to a large extent due to methodological constraints [51]. Cells are fragile, and during filtration the cells are ruptured on the filter, releasing their contents. $\beta$-carotene-rich $D$. salina cells cannot be collected by centrifugation [60]. For ${ }^{14} \mathrm{C}$-tracer experiments, essential information about the carbonate system of the brines and the availability of different forms of inorganic carbon for photosynthesis is generally lacking, and conventional oxygen electrodes perform poorly - if at all - in saturated brines. Therefore, it is difficult to assess the reliability of the few estimates of annual production of hypersaline lakes found in the literature (e.g. $\sim 25 \mathrm{~g} \mathrm{C} \mathrm{m}^{-2}$ year $^{-1}$ for Pink Lake, Victoria, Australia, $\sim 200 \mathrm{~g} \mathrm{C} \mathrm{m}^{-2}$ year $^{-1}$ for Great Salt Lake [78], and $<10 \mathrm{~g}^{-1}$ $\mathrm{C} \mathrm{m}^{-2}$ year $^{-1}$ for Deep Lake, Antarctica [79]).

In a study of the saltern ponds near Alicante, Spain, photosynthetic activity was monitored along the salinity gradient using ${ }^{14} \mathrm{C}$-bicarbonate as a tracer and $3 \mathrm{hrs}$ incubation periods. Maximum carbon incorporation rates 
were obtained in the low salinity $\left(80 \mathrm{~g} \mathrm{l}^{-1}\right)$ ponds. However, in the crystallizer ponds populated by a dense Dunaliella population with a high chlorophyll content very low uptake rates were measured. In brine of $370 \mathrm{~g} \mathrm{l}^{-1}$ salt, rates of 27.5-56 $\mu \mathrm{g} \mathrm{C} \mathrm{l}^{-1}$ day $^{-1}$ were recorded in the light and 20.8-23.8 $\mu \mathrm{g} \mathrm{C} \mathrm{l}^{-1}$ day $^{-1}$ in the dark, values corresponding to $\sim 0.1 \mu \mathrm{g} C$ per $\mu \mathrm{g}$ chlorophyll $a \mathrm{~h}^{-1}$. These low values were attributed to the heavy stress due to the supraoptimal salinity [54]. But the low values reported may also, in part, have been an artifact due to cell lysis during vacuum filtration on $0.2 \mu \mathrm{m}$ polycarbonate filters employed in the study [51], leading to an underestimation of the true carbon fixation rates. In another study of the same saltern, primary production in the crystallizer ponds was below detection limit, despite the presence of $3.5 \mu \mathrm{g} \mathrm{l^{-1 }}$ chlorophyll $a$ of Dunaliella. In ponds of intermediate (200-250 $\mathrm{g} \mathrm{l}^{-1}$ ) salinity with $\sim 3.6 \mu \mathrm{g} \mathrm{l}^{-1}$ chlorophyll $a$ and $74-96 \%$ of the biovolume being Dunaliella (cyanobacteria being present as well at 4-9\%), gross production was estimated at $0.07-1.27 \mu \mathrm{g} C$ per $\mu \mathrm{g}$ chlorophyll $a$ day $^{-1}[80]$.

There also have been attempts to estimate the in situ activity of Dunaliella in saltern brine mesocosms by measuring changes in oxygen concentrations, using a chemical assay (a modification of the Winkler titration) or by means of electrodes. Monitoring diel changes in dissolved oxygen concentrations in mesocosms with crystallizer brine from the salterns of Eilat, Israel (1300$2100 \mathrm{D}$. salina cells $\mathrm{ml}^{-1}$ ) yielded production estimates of $\sim 0.8-1.5 \mu \mathrm{mol} \mathrm{O} \mathrm{O}_{2}^{-1} \mathrm{hr}^{-1}$ [51,81]. These rates, equivalent to $\sim 120-220 \mu \mathrm{g} \mathrm{Cl}^{-1} \mathrm{day}^{-1}$, are significantly higher than those measured in the Spanish salterns populated by denser Dunaliella communities [54]. In another mesocosm experiment with Eilat crystallizer brine (1100 D. salina cells $\mathrm{ml}^{-1}$ ) incubated at $35^{\circ} \mathrm{C}$ in the light and in the dark, changes in oxygen concentration were monitored using an optical oxygen sensor (optode). Calculated production rates were $\sim 1 \mu \mathrm{mol} \mathrm{O} \mathrm{O}_{2} \mathrm{l}^{-1} \mathrm{hr}^{-1}$, equivalent to $\sim 9 \times 10^{-13} \mathrm{~mol} \mathrm{O}_{2}$ cell $^{-1} \mathrm{hr}^{-1}$ (R. Pinhassi, E. Maimon, and A. Oren, unpublished results).

Dunaliella is the key toward the understanding of the functioning of most hypersaline ecosystems as it is the main or sole primary producer on which the heterotrophic components of the ecosystem depend. One of the key compounds linking the activity of the alga with that of the consumers is glycerol, accumulated by Dunaliella in molar concentrations intracellularly as an osmotic stabilizer $[15,79,81]$. To what extent glycerol may diffuse through the membrane of healthy Dunaliella cells is not completely clear. Some studies showed a very low permeability of the Dunaliella membrane to glycerol, but others claim that also in healthy cells significant amounts of glycerol may diffuse continuously into the medium [82]. At temperatures above $40^{\circ} \mathrm{C}$, as regularly encountered in saltern evaporation ponds [55], glycerol leakage maybe significant [83].

\section{Conclusions}

In spite of the in-depth understanding of the properties of Dunaliella strains used for the commercial production of $\beta$-carotene, often under carefully controlled conditions, we know relatively little about the behavior of these species and their closest relatives in their natural environment or in semi-natural systems such as the saltern ecosystem. This is at least in part due to the lack of appropriate methods to study these fragile organisms. But also the potential established with the development of molecular, gene, genomics and proteomics based methods was rarely exploited thus far in the study of the ecology of Dunaliella. The (relative) simplicity of hypersaline ecosystems presents a huge advantage for ecological studies, and Dunaliella is a key component of these ecosystems. Therefore, further exploration of the functioning of Dunaliella in salt lakes and saltern ponds may add much important information, not only toward the understanding of the hypersaline environments, but also for microbial ecology in general.

\section{Competing interests \\ The author declares that he has no competing interests.}

\section{Authors' information}

Aharon Oren (born 1952, Zwolle, the Netherlands) obtained his M.Sc. degree from the University of Groningen and his Ph.D. from the Hebrew University of Jerusalem (1978). After a post-doctoral period at the University of Illinois at Urbana-Champaign he joined the faculty of the Hebrew University of Jerusalem, and was appointed full professor in 1996. His research interests are the microbiology of hypersaline environments, the physiology and biochemistry of halophilic microorganisms, and systematics and nomenclature of prokaryotes. $\mathrm{He}$ is editor-in-chief of the International Journal of Systematic and Evolutionary Microbiology and editor for FEMS Microbiology Letters and Extremophiles. He has served terms as president of the International Society for Salt Lake Research and as chairman and as executive secretary/treasurer of the International Committee on Systematics of Prokaryotes. He was elected Fellow of the American Academy of Microbiology in 2000, and in 2010 he received an honorary doctorate from the University of Osnabrück, Germany.

\section{Acknowledgements}

The author thanks Salt of the Earth Eilat Ltd. for allowing access to the Eilat salterns, and the Interuniversity Institute for Marine Sciences of Eilat for logistic support of his studies of Dunaliella in the Eilat salterns.

Received: 10 October 2014 Accepted: 26 November 2014 Published online: 18 December 2014

\section{References}

1. Teodoresco EC: Organisation et développement du Dunaliella, nouveau genre de Volvocacée-Polyblépharidée. Beih Bot Centralb/ 1905, 18:215-232.

2. Oren A: A hundred years of Dunaliella research: 1905-2005. Saline Systems 2005, 1:2.

3. Dunal F: Les algues qui colorent en rouge certains eaux des marais salants méditerranéens. Ann Sci Nat Bot 2e Sér 1838, 9:172.

4. Baas Becking LGM: Geobiologie of Inleiding tot de Milieukunde. W.P. van Stockum \& Zoon: Den Haag; 1934.

5. Ginzburg M: Dunaliella: a green alga adapted to salt. Adv Bot Res 1987, 14:93-183.

6. Avron M, Ben-Amotz A: Dunaliella: Physiology, Biochemistry, and Biotechnology. Boca Raton: CRC Press; 1992 
7. Ben-Amotz A, Polle JEW, Subba Rao DV: The alga Dunaliella. Biodiversity, Physiology, Genomics and Biotechnology. Enfield, NH: Science Publishers; 2009.

8. Oren A: Book Review. Ben-Amotz, A., Polle, J.E.W. \& Subba Rao, D.V. 2009. The alga Dunaliella. Biodiversity, Physiology, Genomics and Biotechnology. Science Publishers, Enfield, New Hampshire, 555 pp. ISBN 978-1-57808-545-3. J Phycol 2010, 46:216-217.

9. Polle JEW, Tran D, Ben-Amotz A: History, distribution, and habitats of algae of the genus Dunaliella Teodoresco (Chlorophyceae). In The Alga Dunaliella. Biodiversity, Physiology, Genomics and Biotechnology. Edited by Ben-Amotz A, Polle JEW, Subba Rao DV. Enfield, NH: Science Publishers; 2009:1-13

10. Lerche W: Untersuchungen über Entwicklung und Fortpflanzung in der Gattung Dunaliella. Arch Protistenkunde 1937, 88:236-268.

11. Massyuk NP: Morphology, Taxonomy, Ecology and Geographic Distribution of the Genus Dunaliella Teod. and Prospects for its Potential Utilization. Kiev: Naukova Dumka; 1973 (in Russian).

12. Preisig HR: Morphology and taxonomy. In Dunaliella: Physiology, Biochemistry and Biotechnology. Edited by Avron M, Ben-Amotz A. Boca Raton: CRC Press; 1992:1-15.

13. González MA, Gómez PI, Polle JEW: Taxonomy and phylogeny of the genus Dunaliella. In Ben-Amotz A, Polle JEW, Subba Rao DV. Enfield, NH: Science Publishers; 2009:15-44.

14. Borowitzka MA, Siva CJ: The taxonomy of the genus Dunaliella (Chlorophyta, Dunaliellales) with emphasis on the marine and halophilic species. J Appl Phycol 2007, 19:567-590.

15. Borowitzka $L$ : The microflora. Adaptations to life in extremely saline lakes. Hydrobiologia 1981, 81:33-46.

16. González MA, Gómez PI, Montoya R: Comparison of PCR-RFLP analysis of the ITS region with morphological criteria of various strains of Dunaliella. J Appl Phycol 1999, 10:573-580.

17. Olmos J, Paniagua J, Contreras R: Molecular identification of Dunaliella sp. utilizing the 18S rDNA gene. Lett App/ Microbiol 2000, 30:80-84.

18. Olmos J, Ochoa L, Paniagua-Michel J, Contreras R: DNA fingerprinting differentiation between $\beta$-carotene hyperproducer strains of Dunaliella from around the world. Saline Systems 2009, 5:5

19. Olmos-Soto J, Paniagua-Michel J, Contreras R, Ochoa L: DNA fingerprinting intron-sizing method to accomplish a specific, rapid, and sensitive identification of carotenogenic Dunaliella species. Methods Mol Biol 2012, 892:269-281.

20. Hejazi MA, Barzegari A, Gharajeh NH, Hejazi MS: Introduction of a novel $18 \mathrm{~S}$ rDNA gene arrangement along with distinct ITS region in the saline water microalga Dunaliella. Saline Systems 2010, 6:4.

21. Assunção P, Jaén-Molina R, Caujapé-Castells J, de la Jara A, Carmona L, Freijanes K, Mendoza H: Phylogenetic position of Dunaliella acidophila (Chlorophyceae) based on ITS and rbcL sequences. J Appl Phycol 2012, 24:635-639.

22. González MA, Coleman AW, Gómez Pl, Montoya R: Phylogenetic relationship among various strains of Dunaliella (Chlorophyceae) based on nuclear ITS rDNA sequences. J Phycol 2001, 37:604-611.

23. Assunção $P$, Jaén-Molina R, Caujapé-Castells J, Wolf $M$, Buchheim MA, de la Jara A, Freijanes K, Carmona L, Mendoza H: Phylogenetic analysis of ITS2 sequences suggests the taxonomic re-structuring of Dunaliella viridis (Chlorophyceae, Dunaliellales). Phycol Res 2013, 61:81-88.

24. Zamani H, Moradshahi A, Karbalaei-Heidari HR: Characterization of a new Dunaliella salina strain MSI-1 based on nuclear rDNA ITS sequences and its physiological response to changes in composition of growth media. Hydrobiologia 2011, 658:67-75.

25. Assunção P, Jaén-Molina R, Caujapé-Castells J, de la Jara A, Carmona L, Freijanes K, Mendoza H: Molecular taxonomy of Dunaliella (Chlorophyceae), with a special focus on $D$. salina: ITS2 sequences revisited with an extensive geographical sampling. Aquat Biosyst 2012, 8:2.

26. Meuser JE, Baxter BK, Spear JR, Peters JW, Posewitz MC, Boyd ES: Contrasting patterns of community assembly in the stratified water column of Great Salt Lake, Utah. Microb Ecol 2013, 66:268-280.

27. Bodaker I, Sharon I, Suzuki MT, Feingersch R, Shmoish M, Andreishcheva E, Sogin ML, Rosenberg M, Maguire ME, Belkin S, Oren A, Béjà O: Comparative community genomics in the Dead Sea: an increasingly extreme environment. ISME J 2010, 4:399-407.

28. Heidelberg KB, Nelson WC, Holm JB, Eisenkolb N, Andrade K, Emerson JB: Characterization of eukaryotic microbial diversity in hypersaline Lake Tyrrell. Australia Front Microbiol 2013, 4:115.
29. Hamburger C: Zur Kenntnis der Dunaliella salina und einer Amöbe aus Salinenwasser von Cagliari. Arch Protistenkunde 1905, 6:111-131.

30. Borowitzka MA, Huisman JM: The ecology of Dunaliella salina (Chlorophyceae, Volvocales): effect of environmental conditions on aplanospore formation. Bot Mar 1993, 36:233-243.

31. Montoya TH, Olivera GA: Dunaliella salina from saline environments of the central coast of Peru. Hydrobiologia 1993, 267:155-161.

32. Post FJ: The microbial ecology of the Great Salt Lake. Microb Ecol 1977, 3:143-165.

33. Oren A, Ben-Yosef N: Development and spatial distribution of an algal bloom in the Dead Sea: a remote sensing study. Aquat Microb Ecol 1997 13:219-223.

34. Oren A, Gurevich P, Anati DA, Barkan E, Luz B: A bloom of Dunaliella parva in the Dead Sea in 1992: biological and biogeochemical aspects. Hydrobiologia 1995, 297:173-185.

35. Felix EA, Rushford SR: The algal flora of the Great Salt Lake, Utah. USA Nova Hedwigia 1979, 31:163-195.

36. Larson CA, Belovsky GE: Salinity and nutrients influence species richness and evenness of phytoplankton communities in microcosm experiments from Great Salt Lake, Utah, USA. J Plankton Res 2013, 35:1154-1166.

37. Post FJ: Biology of the north arm. In Great Salt Lake: A Scientific, Historical and Economic Overview. Edited by Gwynn JW. Salt Lake City: Utah Geological and Mineral Survey; 1980:314-321.

38. Post FJ: Microbiology of the Great Salt Lake north arm. Hydrobiologia 1981, 81:59-69.

39. Post FJ: Oxygen-rich gas domes of microbial origin in the salt crust of the Great Salt Lake, Utah. Geomicrobiol J 1980, 2:127-139.

40. Stephens DW, Gillespie DM: Phytoplankton production in the Great Salt Lake, Utah, and a laboratory study of algal response to enrichment. Limnol Oceanogr 1976, 21:74-87.

41. Stephens DW: Changes in lake levels, salinity and the biological community of Great Salt Lake (Utah, USA), 1847-1987. Hydrobiologia 1990, 197:139-146.

42. Oren A: The microbial ecology of the Dead Sea. In Advances in Microbial Ecology, Vol. 10. Edited by Marshall KC. New York: Plenum Publishing Company; 1988:193-229.

43. Oren A: Halophilic Microorganisms and their Environments. Dordrecht: Kluwer Scientific Publishers; 2002.

44. Volcani BE: The Microorganisms of the Dead Sea. In Papers Collected to Commemorate the 70th Anniversary of Dr. Chaim Weizmann. Rehovoth: Daniel Sieff Research Institute, Rehovoth; 1944:71-85.

45. Nissenbaum A: The microbiology and biogeochemistry of the Dead Sea. Microb Ecol 1975, 2:139-161.

46. Ben-Amotz A, Ginzburg BZ: Light-induced proton uptake in whole cells of Dunaliella parva. Biochim Biophys Acta 1969, 183:144-154.

47. Oren A, Shilo M: Population dynamics of Dunaliella parva in the Dead Sea. Limnol Oceanogr 1982, 27:201-211.

48. Oren A, Shilo M: Factors determining the development of algal and bacterial blooms in the Dead Sea: a study of simulation experiments in outdoor ponds. FEMS Microbiol Ecol 1985, 31:229-237.

49. Kaplan IR, Friedmann A: Biological productivity in the Dead Sea. Part I. Microorganisms in the water column. Israel J Chem 1970, 8:513-528.

50. Wright SW, Burton HR: The biology of Antarctic saline lakes. Hydrobiologia 1981, 82:319-338.

51. Oren A: Saltern evaporation ponds as model systems for the study of primary production processes under hypersaline conditions. Aquat Microb Ecol 2009, 56:193-204

52. Alfinito $S$, Iberite $M$, Fumanti B: The algal microflora of the salt works of Tarquinia (Italy). Hydrobiologia 1990, 203:137-146.

53. Giani D, Seeler J, Giani L, Krumbein WE: Microbial mats and physicochemistry in a saltern in the Bretagne (France) and in a laboratory scale model. FEMS Microbiol Ecol 1989, 62:151-162.

54. Joint I, Henriksen P, Garde K, Riemann B: Primary production, nutrient assimilation and microzooplankton grazing along a hypersaline gradient. FEMS Microbiol Ecol 2002, 39:245-257.

55. Rodriguez-Valera F, Ventosa A, Juez G, Imhoff JF: Variation of environmental features and microbial populations with salt concentrations in a multi-pond saltern. Microb Ecol 1985, 11:107-115.

56. Javor BJ: Industrial microbiology of solar salt production. J Ind Microbio/ Biotechnol 2002, 28:42-47. 
57. Javor BJ: Planktonic standing crop and nutrients in a saltern ecosystem. Limnol Oceanogr 1983, 28:153-159.

58. Dolapsakis NP, Tafas T, Abatzopoulos TJ, Ziller S, Economou-Amilli A: Abundance and growth response of microalgae at Megalon Embolon solar saltworks in northern Greece: an aquaculture prospect. J Appl Phycol 2005, 17:39-49.

59. Oren A, Rodríguez-Valera F: The contribution of halophilic Bacteria to the red coloration of saltern crystallizer ponds. FEMS Microbiol Ecol 2001, 36:123-130.

60. Oren A, Dubinsky Z: On the red coloration of saltern crystallizer ponds. II. Additional evidence for the contribution of halobacterial pigments. Int J Salt Lake Res 1994, 3:9-13.

61. Oren A, Stambler N, Dubinsky Z: On the red coloration of saltern crystallizer ponds. Int J Salt Lake Res 1992, 1:77-89.

62. Oren A: Microbial diversity and microbial abundance in salt-saturated brines: why are the waters of hypersaline lakes red? In Saline Lakes around the World: Unique Systems with Unique Values. Edited by Oren A, Naftz DL, Palacios P, Wurtsbaugh WA. Salt Lake City: The S.J. and Jessie E. Quinney Natural Resources Research Library, College of Natural Resources, Utah State University; 2009:247-255.

63. Mishra A, Jha B: Isolation and characterization of extracellular polymeric substances from micro-algae Dunaliella salina under salt stress. Bioresour Technol 2009, 100:3382-3386.

64. Davis JS, Giordano M: Biological and physical events involved in the origin, effects, and control of organic matter in solar saltworks. Int J Salt Lake Res 1996, 4:335-347.

65. Giordano M, Bargnesi F, Mariani P, Ratti S: Dunaliella salina (Chlorophyceae) affects the quality of $\mathrm{NaCl}$ crystals. Cryprogam Algol 2014, 35:285-302.

66. Giordano M, Beardall J: Impact of environmental conditions on photosynthesis, growth and carbon allocation strategies of hypersaline species of Dunaliella. Global NEST J 2009, 11:79-85.

67. Buchheim MA, Kirkwood AE, Buchheim JA, Verghese B, Henley WJ: Hypersaline soil supports a diverse community of Dunaliella (Chlorophyceae). J Phycol 2010, 46:1038-1047.

68. Azúa-Bustos A, González-Silva C, Salas L, Palma RE, Vicuña R: A novel subaerial Dunaliella species growing on cave spiderwebs in the Atacama Desert. Extremophiles 2010, 14:443-452.

69. DiGregorio BE: Pleistocene microbes recovered from halite inclusions prove viable. Microbe 2011, 6:260-261.

70. Lowenstein TK: Microorganisms in Evaporites: Review of Modern Geomicrobiology. In Advances in Understanding the Biology of Halophilic Microorganisms. Edited by Vreeland RH. Dordrecht: Springer Science and Business Media; 2012:117-139.

71. Schubert BA, Timofeeff MN, Lowenstein TK, Polle JEW: Dunaliella cells in fluid inclusions in halite: significance for long-term survival of prokaryotes. Geomicrobiol J 2010, 27:61-75.

72. Schubert BA, Lowenstein TK, Timofeeff MN, Parker MA: How do prokaryotes survive in fluid inclusions in halite for 30 k.y.? Geology 2009, 37:1059-1062.

73. Lowenstein TK, Schubert BA, Timofeeff MN: Microbial communities in fluid inclusions and long-term survival in halite. GSA Today 2011, 21:4-9.

74. Conner AJ, Benison KC: Acidophilic halophilic microorganisms in fluid inclusions in halite from Lake Magic, Western Australia. Astrobiology 2013, 13:850-860.

75. Benison KC, Karmanocky FJ III: Could microorganisms be preserved in Mars gypsum? Insights from terrestrial examples. Geology 2014, 42:615-618.

76. Brock TD: Salinity and the ecology of Dunaliella from Great Salt Lake. J Gen Microbiol 1975, 89:285-292.

77. Moulton TP, Sommer TR, Burford MA, Borowitzka LJ: Competition between Dunaliella species at high salinity. Hydrobiologia 1987, 151/152:107-116.

78. Hammer UT: Primary production in saline lakes. Hydrobiologia 1981, $81: 47-57$.

79. Williams TJ, Allen MA, DeMaere MZ, Kyrpides NC, Tringe SG, Woyke T, Cavicchioli R: Microbial ecology of an Antarctic hypersaline lake: genomic assessment of ecophysiology among dominant haloarchaea. ISME J 2014, 8:1645-1658.

80. Pedrós-Alió C, Calderón-Paz Jl, MacLean MH, Medina G, Marassé C, Gasol JM, Guixa-Boixereu N: The microbial food web along salinity gradients. FEMS Microbiol Ecol 2000, 32:143-155.
81. Elevi Bardavid R, Khristo P, Oren A: Interrelationships between Dunaliella and halophilic prokaryotes in saltern crystallizer ponds. Extremophiles 2008, 12:5-14.

82. Enhuber G, Gimmler H: The glycerol permeability of the plasmalemma of the halotolerant green alga Dunaliella parva (Volvocales). J Phycol 1980, 16:524-532.

83. Wegmann K, Ben-Amotz A, Avron M: Effect of temperature on glycerol retention in the halotolerant algae Dunaliella and Asteromonas. Plant Physiol 1980, 66:1196-1197.

\section{Submit your next manuscript to BioMed Central and take full advantage of:}

- Convenient online submission

- Thorough peer review

- No space constraints or color figure charges

- Immediate publication on acceptance

- Inclusion in PubMed, CAS, Scopus and Google Scholar

- Research which is freely available for redistribution

Submit your manuscript at www.biomedcentral.com/submit
C Biomed Central 